\title{
Electrochemical Detection of DNA Triplet Repeat Expansion
}

Miroslav Fojta ${ }^{*}$ Ludek Havran, Marie Vojtiskova and Emil Palecek ${ }^{*}$

Institute of Biophysics, Academy of Sciences of the Czech Republic, Kralovopolská 135, 612 65 Brno, Czech Republic

\section{SUPPORTING INFORMATION}

\section{Experimental Section}

\section{Material.}

Dynabeads Oligo $(\mathrm{dT})_{25}\left(\mathrm{~B}_{\mathrm{T}}\right)$ and magnetic particle concentrator MPC-S were supplied by Dynal A.S. Plasmid DNAs pRW3821 and pRW3822, containing inserts of a frataxin gene segment involving $(\mathrm{GAA})_{59}$ or $(\mathrm{GAA})_{150}$ triplet repeats ${ }^{1}$, respectively, were kindly donated by Professor R.D. Wells. The DNAs were purified using Qiagen Plasmid Purification Kit (Qiagen, Germany) and cleaved by restrictases Eco RI, Bgl I, Hind III, Pvu II and/or Pst I (Takara, Japan) in various combinations to prepare DNA fragments containing the frataxin insert of different lengths. PCR products GGGATTGGTTGCCAGTGCTT AAAAGTTAGGACTTAGAAAATGGATTTCCTGGCAGGACGCGGTGGCTCATGCCCAT AATCTCAGCACTTTGGGAGGCCTAGGAAGGTGGATCACCTGAGGTCCGGAGTTCA AGACTAACCTGGCCAACATGGTGAAACCCAGTATCTACTAAAAAATACAAAAAAA

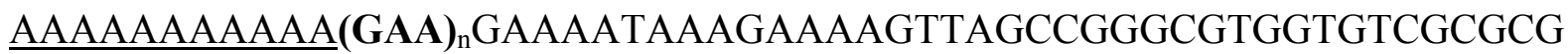
CCTGTAATCCCAGCTACTCCAGAGGCTGCGGCAGGAGAATCGCTTGAGCCCGGGA GGCAGAGGTTGCATTAAGCCAAGATCGCCCAATGCACTCCGGCCTGGGCGACAGA GCAAGACTCCGTCTCAAAAAATAATAATAATAAATAAAAATAAAAAATAAAATGG 
ATTTCCCAGCATCTCTGGAAAAATAGGCAAGTGTGGCCATGATGGTCCTTAGATC (in the sequence, segments spanning the primer binding sites are in italics, the triplet repeat in bold and the $\mathrm{A}_{18}$ stretch used for target DNA (tDNA) immobilization at the $\mathrm{B}_{\mathrm{T}}$ underlined) were prepared using primers GAA-F and GAA-R ${ }^{2}$ on templates of the pRW3821 (amplicon RW59) or pRW3822 (amplicon RW150), or of patients' genomic DNAs. PCR primers were purchased from VBC-GENOMICS (Austria), the reporter probe (TTC) 12 biotinylated at its 5'-end (RPbiot) from the Laboratory of Plant Molecular Physiology, Masaryk University, Brno (Czech Republic).

\section{DNA modification with osmium tetroxide, 2,2'-bipyridine (Os,bipy).}

Thermally denatured DNA samples (50-100 $\mathrm{ng} \mu \mathrm{l}^{-1}$ ) were treated with $2 \mathrm{mM} \mathrm{OsO}_{4}(\mathrm{JMC}, \mathrm{UK})$ and $2 \mathrm{mM}$ 2,2'-bipyridine (Sigma) in $0.1 \mathrm{M}$ Tris- $\mathrm{HCl}(\mathrm{pH}$ 7.4). The reaction was carried out at $37{ }^{\circ} \mathrm{C}$ for $3 \mathrm{~h}$. Free Os,bipy was removed by ultrafiltration with Microcon YM-50 (Millipore, USA). Concentrations of osmium-modified DNAs were determined voltammetrically ${ }^{3}$.

\section{DNA hybridization at magnetic beads.}

$40 \mu \mathrm{l}$ of tDNA solution in $0.3 \mathrm{M} \mathrm{NaCl}, 10 \mathrm{mM}$ Tris- $\mathrm{HCl} \mathrm{pH} 7.6$ (buffer $\mathrm{H}$ ) was added to $\mathrm{B}_{\mathrm{T}}$ (20 $\mu \mathrm{l}$ of the suspension per sample) previously washed twice by $40 \mu \mathrm{l}$ of the buffer $\mathrm{H}$ (in all steps, the beads were separated from the supernatant using the magnetic concentrator and resuspended in a new medium by short vortexing $)^{4-8}$. The mixtures were shaken in the Thermomixer Comfort (Eppendorf) for $30 \mathrm{~min}$ at $20{ }^{\circ} \mathrm{C}$ to allow hybridization between $\mathrm{A}_{18}$ stretches of the tDNA and the $\mathrm{T}_{25}$ capture probes on the beads surface. After capturing of the tDNA, the beads were washed twice by $100 \mu \mathrm{l}$ of the buffer $\mathrm{H}$, and the suspension was split into two aliquots. For the measurements of osmium-labeled tDNA ${ }^{4}$, the latter was released from one portion (aliquot I) of the beads into $10 \mu \mathrm{l}$ of TE buffer by heating the $\mathrm{B}_{\mathrm{T}}$ suspension 
at $85{ }^{\circ} \mathrm{C}$ for $2 \mathrm{~min}$. Prior to DNA adsorption at the electrode, $\mathrm{NaCl}$ was added to each sample to a final concentration of $0.2 \mathrm{M}$.

\section{Electrochemical enzyme-linked DNA hybridization assay at $\mathbf{B}_{\mathrm{T}}$.}

The RP-biot in $20 \mu \mathrm{l}$ of the buffer $\mathrm{H}$ was added to the other portion of the beads (aliquot II) with captured tDNA and shaken for 5 min under conditions mentioned above. The beads were then washed twice by $50 \mu \mathrm{l}$ of buffer $\mathrm{H}$ followed by blocking of the bead surface by 15 -min incubation in $50 \mu \mathrm{l}$ of $0.14 \mathrm{M} \mathrm{NaCl}, 3 \mathrm{mM} \mathrm{KCl}, 4 \mathrm{mM} \mathrm{Na}_{2} \mathrm{PO}_{4} \mathrm{pH} 7.4$ (PBS) with $5 \%$ of dried milk (PBSM). Then, streptavidin-alkaline phosphatase conjugate (SALP; Promega) was added (1:100 diluted stock solution in $50 \mu \mathrm{l}$ of PBSM) and the suspension was shaken for $30 \mathrm{~min}$, followed by washing 4-times with $0.05 \%$ Tween 20 in PBS (PBST) and twice by $50 \mu$ of buffer $\mathrm{H}$. Finally, $50 \mu \mathrm{l}$ of $0.1 \mathrm{M}$ 1-naphthyl phosphate in $0.5 \mathrm{M} \mathrm{K}_{2} \mathrm{CO}_{3}$ and $0.5 \mathrm{M} \mathrm{Na}_{2} \mathrm{HCO}_{3}$, $\mathrm{pH} 9.5$ was added to the beads and the suspension was shaken for $30 \mathrm{~min}$. Prior to voltammetric detection of the resulting 1-naphthol, $\mathrm{B}_{\mathrm{T}}$ were removed and the supernatant was diluted into $1 \mathrm{ml}$ of the same carbonate buffer. All steps were performed at $20{ }^{\circ} \mathrm{C}$. The 1 naphthol was determined by linear sweep voltammetry (LSV) at the PGE using an irreversible anodic signal (peak N, Fig. 1C) ${ }^{7,9,10}$.

\section{Electrochemical measurements of Os,bipy-labeled tDNA.}

Os,bipy-labeled DNA (DNA-Os,bipy) was analyzed by means of either adsorptive transfer stripping (AdTS) square-wave voltammetry (SWV) at a pyrolytic graphite electrode (PGE) (Fig. 1A), or AdTS differential pulse voltammetry (DPV) at a hanging mercury drop electrode (HMDE) (Fig. 1B). The DNA-Os,bipy yields three redox couples at carbon ${ }^{3}$ and mercury ${ }^{11}$ electrodes. Peak $\alpha$ (Fig. 1A) is the most negative anodic signal obtained at the carbon electrodes $^{3,4}$ [probably due to oxidation of Os(II) to Os(III)]. At the HMDE a more negative 
signal can be observed at $-1.2 \mathrm{~V}^{12,13}$ (peak Os, Fig. 1B) which is due to catalytic hydrogen evolution $^{11,13}$. Subnanomolar concentrations of DNA-Os,bipy can be detected by this peak at moderate accumulation times ${ }^{13}$.

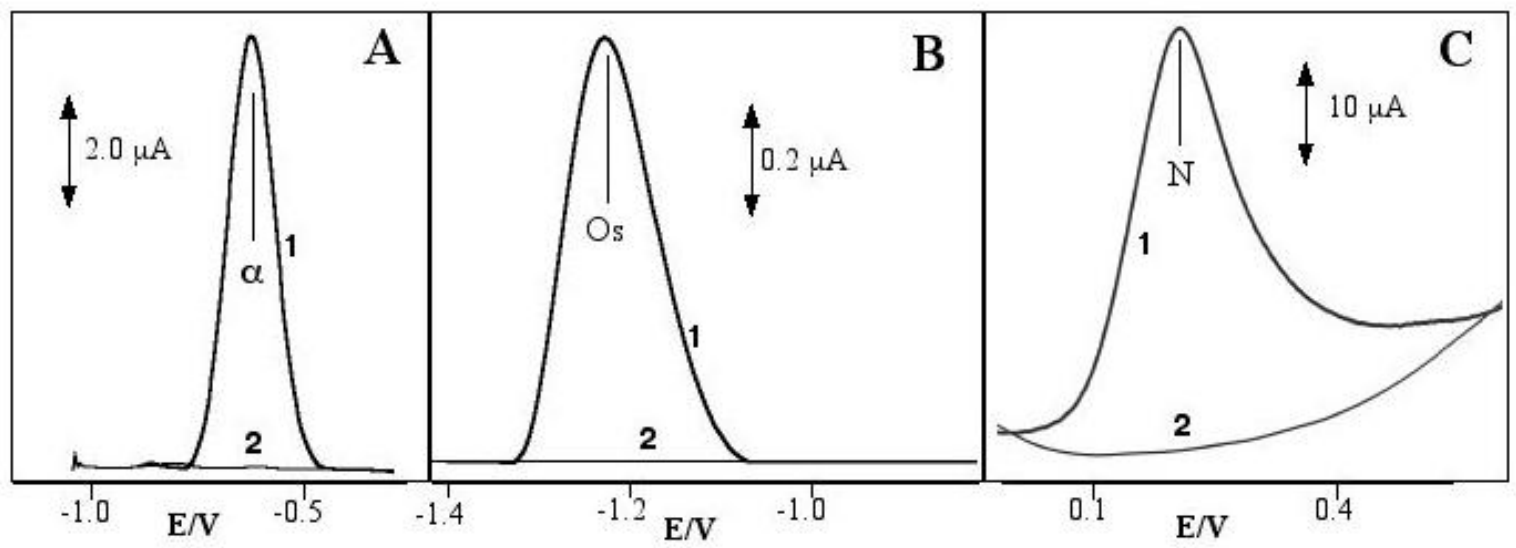

Figure 1. Electrochemical signals (A,B), of Os,bipy-modified tDNAs and (C), arising from the electrochemical enzyme-linked RP-biot hybridization assay. (A), peak $\alpha$ yielded by Os,bipy-modified DNA at the PGE obtained as response of tDNA captured at the $\mathrm{B}_{\mathrm{T}}$. Target RW59 PCR product was captured at $10 \mu \mathrm{l}$ of the $\mathrm{B}_{\mathrm{T}}$ suspension from $20 \mu \mathrm{l}$ of $10 \mathrm{ng}^{-1} \mathrm{l}^{-1}$ solution of the amplicon, followed by washing and thermal tDNA release from the beads. The DNA osmium label was detected using square-wave voltammetry at the PGE (accumulation time $60 \mathrm{~s}$, electrode surface area $10.5 \mathrm{~mm}^{2}$; curve 1). No peak was obtained when an Os,bipy-modified pBluescript DNA (not containing the $\mathrm{A}_{18}$ stretch) was incubated with the beads instead of the RW59 (curve 2). (B), catalytic osmium peak obtained for the Os,bipy-modified RW59 tDNA at a hanging mercury drop electrode (HMDE). The experiment was performed as in (A) but with $0.5 \mathrm{ng} \mu \mathrm{l}^{-1}$ of the tDNA. The osmium label was detected by means of differential pulse voltammetry at the HMDE (accumulation time $60 \mathrm{~s}$, electrode surface area $0.4 \mathrm{~mm}^{2}$; curve 1). Curve 2 corresponds to a negative control ( $5 \mathrm{ng} \mathrm{\mu l}^{-1}$ of Os,bipy-modified pBluescript DNA). (C), peak of 1naphthol obtained in the enzyme-linked RP-biot hybridization assay. (Curve 1), the Os,bipy pre-labeled RW59 amplicon was captured at the $\mathrm{B}_{\mathrm{T}}$ as in (A), followed by a $5 \mathrm{~min}$ hybridization with $5 \mathrm{ng} \mu \mathrm{l}^{-1}$ of biotinylated RPbiot, binding of the streptavidin-alkaline phosphatase conjugate (SALP), and incubation of the beads in $1 \mathrm{mM} \mathrm{1-}$ naphthyl phosphate, $0.5 \mathrm{M} \mathrm{NaHCO}_{3} / \mathrm{K}_{2} \mathrm{CO}_{3}, \mathrm{pH}$ 9.5. The 1-naphthol was determined by linear sweep voltammetry at the PGE. Curve 2 was obtained when a 950-bp fragment of plasmid pSP64(polyA) containing $\mathrm{A}_{30}$ stretch but lacking the $(\mathrm{GAA})_{\mathrm{n}}$ repeat was captured at the beads instead of the target RP150 PCR product (for more details see Experimental Section). 
Surface of the PGE was renewed and DNA adsorbed at the electrodes as described previously $^{3,13,14}$. All measurements were performed at room temperature with a three-electrode system involving PGE or $\mathrm{HMDE}$ as working, $\mathrm{Ag} / \mathrm{AgCl} / 3 \mathrm{M} \mathrm{KCl}$ electrode as a reference and platinum wire as an auxiliary electrode. SWV measurements were carried out in $0.2 \mathrm{M}$ acetate buffer ( $\mathrm{pH}$ 5.0) on air using a CHI440 Electrochemical Workstation (CH Instruments, Inc., USA) with the following settings: initial potential $-1.0 \mathrm{~V}$, quiescent time $2 \mathrm{~s}$, pulse amplitude $25 \mathrm{mV}$, frequency $200 \mathrm{~Hz}$, potential step $5 \mathrm{mV}$, final potential $+0.1 \mathrm{~V}$. LSV measurements were performed with the same instrument in $0.5 \mathrm{M} \mathrm{K}_{2} \mathrm{CO}_{3}, 0.5 \mathrm{M} \mathrm{Na}_{2} \mathrm{HCO}_{3}$, pH 9.5, with initial potential $-0.5 \mathrm{~V}$, end potential $+0.8 \mathrm{~V}$, scan rate $1 \mathrm{~V} \mathrm{~s}^{-1}$, potential step $5 \mathrm{mV}$. The DPV measurements were performed using an Autolab analyzer (Eco Chemie, The Netherlands) connected to a VA-Stand 663 (Metrohm, Zurich, Switzerland), in deaerated Britton-Robinson buffer $\mathrm{pH} 3.9$, with pulse amplitude $50 \mathrm{mV}$, initial potential $-0.6 \mathrm{~V}$, potential step $5 \mathrm{mV}$, interval time $0.5 \mathrm{~s}$, final potential -1.6 . For five parallel $\mathrm{B}_{\mathrm{T}}$ hybridization assays, standard deviations of tDNA-Os,bipy determination were 14 and $11 \%$ for peak $\alpha\left(2.5 \mathrm{ng} \mu \mathrm{l}^{-1} \mathrm{RW} 59\right)$ and peak Os (0.5 ng $\left.\mu \mathrm{l}^{-1} \mathrm{RW} 59\right)$, respectively. When the same tDNA samples were measured without the $\mathrm{B}_{\mathrm{T}}$ hybridization step, the standard deviations were 8 and $4 \%$, respectively. The RP-biot enzyme-linked assay of the triplet repeat in RW59 $\left(2.5 \mathrm{ng} \mu \mathrm{l}^{-1}\right)$ exhibited a $15 \%$ standard deviation.

\section{OPTIMIZATION AND CALIBRATION OF THE TECHNIQUE}

Effects of the RP-biot concentration. Either RW59 (involving 59 GAA triplets, total length including flanking sequences $628 \mathrm{bp}$ ) or RW150 (150 triplets, total length $901 \mathrm{bp}$ ) PCR products $\left(10 \mathrm{ng} \mu \mathrm{l}^{-1}\right)$ were captured at the beads as the tDNAs, followed by hybridization with different concentrations of the RP-biot (Fig. 2) and the enzyme-linked electrochemical assay. 
For RW59, peak N increased with the RP-biot concentration about linearly from 0 to $0.25 \mathrm{ng}$ $\mu l^{-1}$ (Fig. 2) and leveled off at higher concentrations, suggesting saturation of the RP-biot

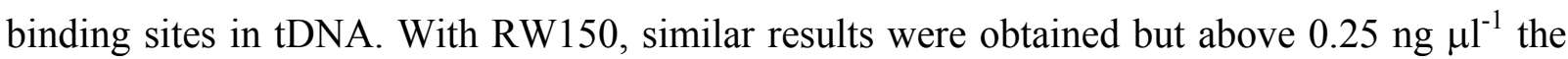
peak $\mathrm{N}$ increased less steeply up to about $1 \mathrm{ng} \mu \mathrm{l}^{-1}$ where the saturation was reached (Fig. 2). The maximum peak N height of RW150 was 3-times higher than that of the RW59 amplicon in agreement with the relation between the amount of bound RP-biot and the length of the repetitive sequences (Fig. 2, inset). In further experiments, $5 \mathrm{ng} \mu \mathrm{l}^{-1}$ of the RP-biot and tDNA concentrations 5 to $10 \mathrm{ng} \mathrm{ml}^{-1}$ were used.

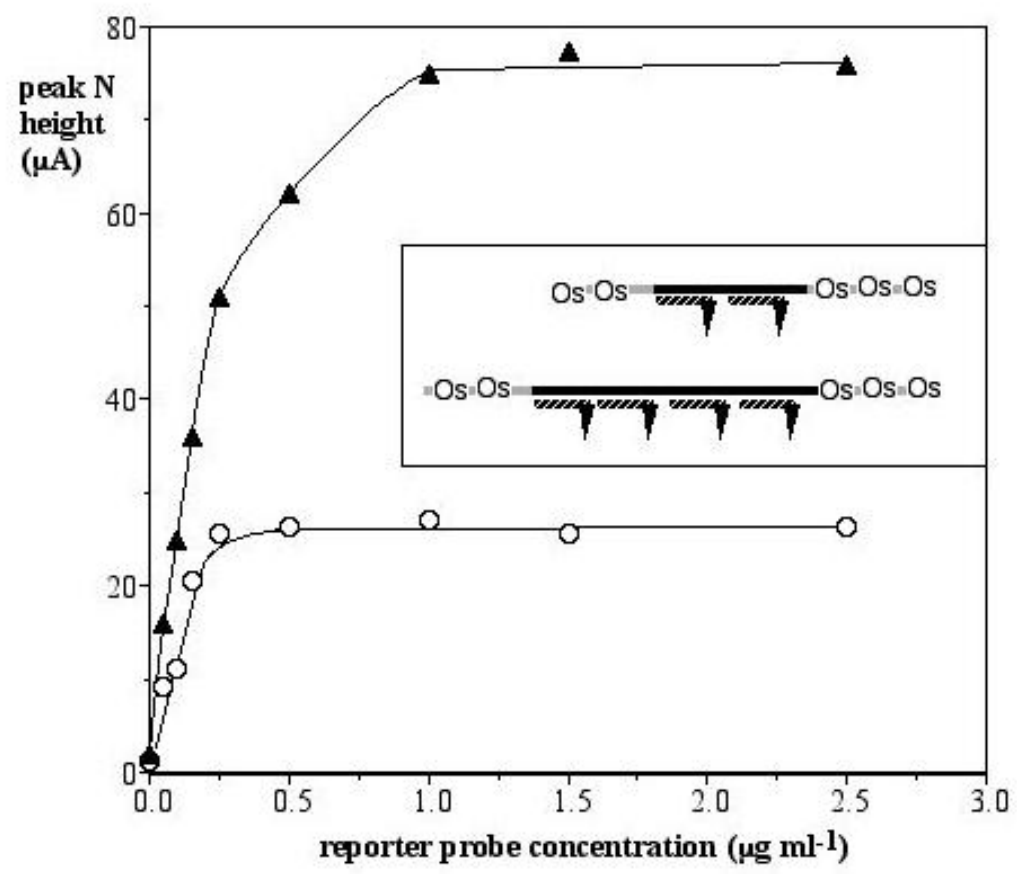

Figure 2. Dependence of the peak N height on the RP-biot concentration for tDNA amplicons (O), RW59 (59 repeats) and $(\boldsymbol{\Delta})$, RW150 (150 repeats). Osmium-premodified tDNAs (10 ng $\left.\mu \mathrm{l}^{-1}\right)$ were captured at the $\mathrm{B}_{\mathrm{T}}$ followed by hybridization with RP-biot at concentrations given in the graph. The following steps were performed as in Fig. 1C. Inset: scheme of RP-biot multiple binding to the expanded triplet repeat.

Effects of the tDNA concentration on the peak $\alpha$ and peak N was studied for the RW59 and RW150 amplicons. The results are shown and discussed in the Communication (Fig. 2A,B). 
Determination of the tDNA at mercury electrodes. The DNA-Os,bipy peak $\alpha$ offers a lower sensitivity of DNA determination than the peak $\mathrm{N}$ arising from the RP-biot assay involving biocatalytic process. Close to the peak $\alpha$ detection limits, the $\mathrm{N} / \alpha$ ratio depends on sample concentration, making the assay less reliable in this concentration range (Fig. 2B in the Communication). It is usually easy to amplify sufficient amounts of the tDNA ( $\sim 50-100$ ng per sample) and work in the range where $\mathrm{N} / \alpha$ is concentration-independent. At lower tDNA concentrations we used a more sensitive detection of the Os,bipy-labeled tDNA at mercury electrodes (Fig. 3 here) ${ }^{13}$. By means of the catalytic osmium peak (peak Os, Fig. 1B) ${ }^{12,13,15}$ it was possible to detect reproducibly the osmium-prelabeled RW150 amplicon captured at the

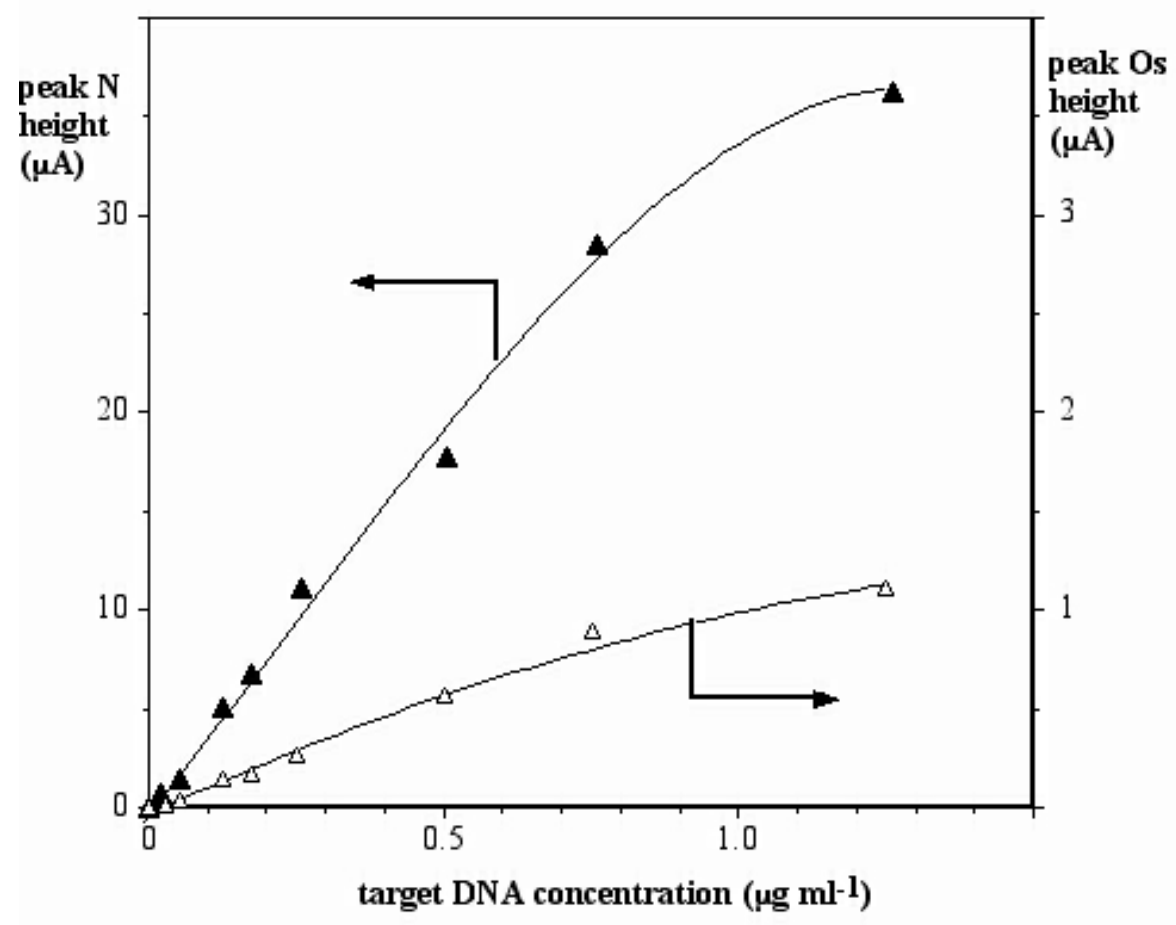

Figure 3. Dependence of the heights of the tDNA and RP-biot signals on the concentration of RW150: ( $\Delta$ ), catalytic peak Os (measured at the HMDE) of tDNA-Os,bipy; ( $\boldsymbol{\Delta})$, peak N (measured at PGE) obtained in the enzyme-linked RP-biot hybridization assay. The Os,bipy-premodified PCR products (at concentrations indicated in the graph) were captured at $20 \mu \mathrm{l}$ of the $\mathrm{B}_{\mathrm{T}}$ from $40-\mu \mathrm{l}$ samples. After washing, the $\mathrm{B}_{\mathrm{T}}$ suspensions were divided into two equal portions which were further analyzed as in Fig. 1. For more details see Experimental Section. 
beads at concentrations as low as $10 \mathrm{pg}^{-1} \mathrm{l}^{-1}$ (200 pg in a $20 \mu \mathrm{l}$ sample) after a 60-s accumulation. Practically constant values of the normalized signal (N/Os) of the (GAA) $)_{150}$ repeat were obtained for tDNA concentrations down to $175 \mathrm{pg}^{\mathrm{f}^{-1}}$ (relative standard deviation $19 \%$ ). The RP-biot enzyme-linked hybridization assay yielded well measurable signals (peak

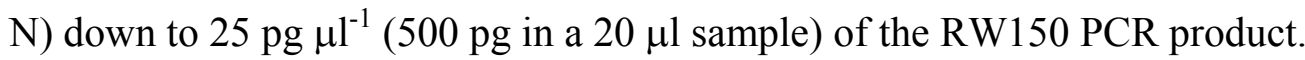

Effects of non-specific DNAs. The assays were performed with $1 \mathrm{ng} \mu \mathrm{l}^{-1}$ of the RW59 tDNA to which various amounts (up to 1000-fold excess) of denatured plasmid pBluescript or calf thymus DNAs were added prior to the tDNA premodification by Os,bipy. The plasmid DNA exhibited no significant effect on the peak $\mathrm{N}$ or peak $\alpha$ heights up to a 500 -fold mass excess. For the 1000-fold excess of the pBluescript, 10 to $20 \%$ decrease of the signals was observed. Calf thymus DNA was apparently without effect up to its 100-fold excess. Higher amounts of the calf thymus DNA caused a more significant decrease of the peak N (about 20 and $30 \%$ for 500-fold and 1000-fold excesses, respectively) and increase of peak $\alpha$ (by 30 and $50 \%$, respectively). This behavior was probably due to collateral hybridization of a portion of the Os,bipy-modified calf thymus DNA at the $\mathrm{B}_{\mathrm{T}}$ via $\mathrm{A}_{\mathrm{n}}$ stretches spread in the eukaryotic genomic DNA $^{5}$

Effects of the length of "random" sequences flanking the triplet repeat. By means of restriction cleavage of the pRW3821 plasmid, DNA fragments of different lengths $(\sim 1,1.7$, 2.9, 4.8 and $7 \mathrm{~kb}$ ) containing the frataxin gene insert [including the $\mathrm{A}_{18}$ stretch and (GAA) 59 trinucleotide repeat] were prepared. The plasmid digests were Os,bipy-premodified and analyzed by the $\mathrm{B}_{\mathrm{T}}$ electrochemical hybridization assay (using the PGE). Peak $\alpha$ of tDNAOs,bipy increased linearly with the fragment length between 1 and $2.9 \mathrm{~kb}$, in agreement with increasing number of osmium labels bound to the 


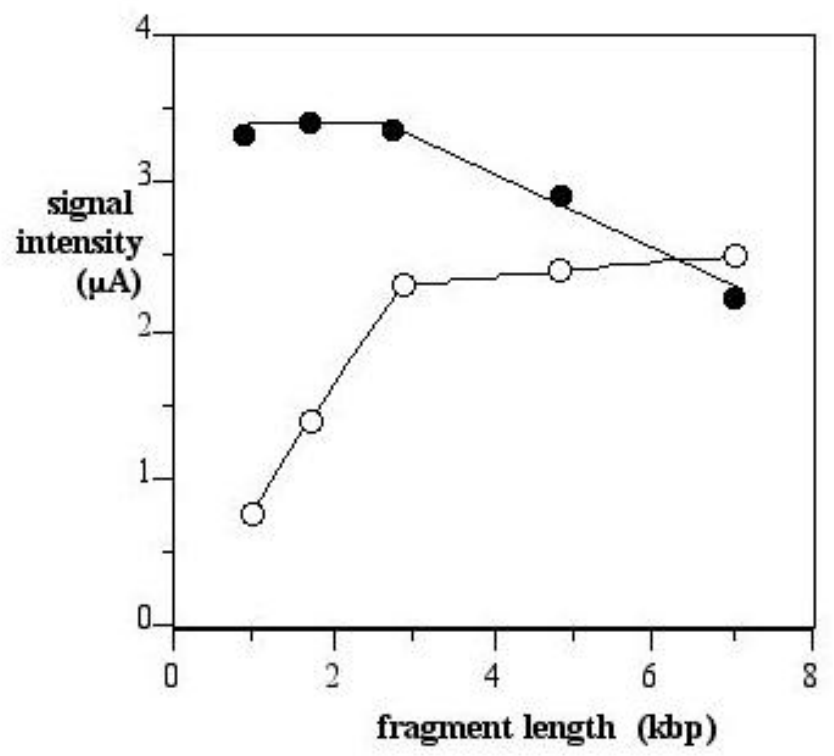

Figure 4. Dependence of the height of (०), peak $\alpha$; and (•), peak N, on the length of different pRW3821 tDNA fragments [all containing $(\mathrm{GAA})_{59}$ repeat]. The plasmid DNA was cleaved by different restrictases (see Experimenal). The DNA digests were osmium-premodified and fragments with the frataxin insert (containing the GAA triplet repeat and the $\mathrm{A}_{18}$ stretch) were captured at $\mathrm{B}_{\mathrm{T}}$ from $20 \mathrm{ng} \mathrm{ll}^{-1}$ of total DNA. For other details see Fig. 1.

longer DNA fragments. For the longest tDNA fragments, the peak $\alpha$ intensity increased less steeply (Fig. 4). Height of peak N from the RP-biot hybridization was apparently independent on the fragment length up to $2.9 \mathrm{~kb}$ and decreased for longer tDNA fragments. This behavior suggests that changing tDNA fragment lengths between about 1 and $3 \mathrm{~kb}$ significantly affected neither capturing of the tDNA at the $\mathrm{B}_{\mathrm{T}}$ (peak $\alpha$ increased linearly with the tDNA length), nor hybridization of the reporter probe (for a constant length of the triplet repeat, the height of peak $\mathrm{N}$ was also constant). Our results obtained with other tDNAs involving $A_{n}$ stretches (hybridizing with the $\mathrm{B}_{\mathrm{T}}$ ) suggest that the linear dependence between the tDNA length at peak $\alpha$ intensity extends at least down to $400 \mathrm{bp}$ (not shown). DNA fragments longer than $3 \mathrm{~kb}$ probably hybridized with the $\mathrm{B}_{\mathrm{T}}$ less efficiently which resulted in the break on the dependence of peak $\alpha$ height on the fragment length, and in the decrease of peak $\mathrm{N}$ for the longer tDNAs. 
These results might have important implications regarding general applicability of the proposed technique: (i) With the GAA-F and GAA-R PCR primers (used in this work and usually applied in current DNA diagnostics of $\mathrm{FRDA}^{2}$ ), the length of the trinucleotide repeat corresponding to $\sim 3 \mathrm{~kb}$ amplicon is $\sim 800$ triplet units (see Experimental Section). It can be therefore expected that detection of the triplet expansion in most of the FRDA patients and carriers by this technique will not be significantly affected by the total amplicon length. (ii) Choice of PCR primers is in principle not limited to those used in this paper, because length of the flanking sequences does not significantly influence the RP-biot signal in a wide range (Fig. 4).

\section{Scope of the technique.}

The main aim of genetic screening of the population is early recognition of mutations potentially affecting health of the patient or his progeny. In the case of triplet expansion, identification of asymptomatic heterozygous carriers of the mutated alleles is particularly important. As documented by our results, mutated allele involving the expanded (GAA) $)_{n}$ triplet repeat can easily be recognized in the presence of normal allele (Fig. 2 in the Communication). This is sufficient for the preliminary screening even when the method yields an average signal of both alleles (the response is not allele-specific). In the case of FRDA, the protocol utilizes specific features of the frataxin genomic locus (involving the $\mathrm{A}_{18}$ stretch used for the tDNA capturing at $\mathrm{B}_{\mathrm{T}}$ ) and the homopurine.homopyrimidine nature of the triplet repeat, allowing for selective Os,bipy modification of the homopyrimidine strand. Our preliminary results suggest that the Os,bipy labeling can easily be applied also for sequences flanking stretches containing cytosine but not thymine residues $\left[\right.$ such as $\left.(\mathrm{CAG})_{\mathrm{n}}\right]$. Sequences suitable for tDNA immobilization can be attached to the tDNA by the PCR. Principles of the method can thus be 
applied in detection of expansion of other triplets related to neurodegenerative diseases ${ }^{16}$ as well as in determination of the length of any repetitive sequence.

\section{REFERENCES}

(1) Ohshima, K.; Montermini, L.; Wells, R. D.; Pandolfo, M. J. Biol. Chem. 1998, 273, 14588-14595.

(2) Campuzano, V.; Montermini, L.; Molto, M. D.; Pianese, L.; Cossee, M.; Cavalcanti, F.; Monros, E.; Rodius, F.; Duclos, F.; Monticelli, A.; Zara, F.; Canizares, J.; Koutnikova, H.; Bidichandani, S. I.; Gellera, C.; Brice, A.; Trouillas, P.; De Michele, G.; Filla, A.; De Frutos, R.; Palau, F.; Patel, P. I.; Di Donato, S.; Mandel, J.-L.; Cocozza, S.; Koenig, M.; Pandolfo, M. Science 1996, 271, 1423-1427.

(3) Fojta, M.; Havran, L.; Kizek, R.; Billova, S. Talanta 2002, 56, 867-874.

(4) Fojta, M.; Havran, L.; Billova, S.; Kostecka, P.; Masarik, M.; Kizek, R. Electroanalysis 2003, 15, 431-440.

(5) Palecek, E.; Billova, S.; Havran, L.; Kizek, R.; Miculkova, A.; Jelen, F. Talanta 2002, 56, 919-930.

(6) Palecek, E.; Fojta, M.; Jelen, F. Bioelectrochemistry 2002, 56, 85-90.

(7) Palecek, E.; Kizek, R.; Havran, L.; Billova, S.; Fojta, M. Anal. Chim. Acta 2002, 469, 73-83.

(8) Jelen, F.; Yosypchuk, B.; Kourilova, A.; Novotny, L.; Palecek, E. Anal. Chem. 2002, 74, 4788-4793.

(9) Gehring, A. G.; Brewster, J. D.; Irwin, P. L.; Tu, S. I.; Van Houten, L. J. J. Electroanal. Chem. 1999, 469, 27-33.

(10) Wang, J.; Xu, D.; Erdem, A.; Polsky, R.; Salazar, M. A. Talanta 2002, 56, 931-938.

(11) Havran, L.; Fojta, M.; Palecek, E. Bioelectrochemistry 2004, in press.

(12) Palecek, E.; Hung, M. A. Anal. Biochem. 1983, 132, 236-242.

(13) Kizek, R.; Havran, L.; Fojta, M.; Palecek, E. Bioelectrochemistry 2002, 55, 119-121.

(14) Palecek, E. Talanta 2002, 56, 809-819.

(15) Jelen, F.; Karlovsky, P.; Pecinka, P.; Makaturova, E.; Palecek, E. Gen. Physiol. Biophys. 1991, 10, 461-473.

(16) Paulson, H. L.; Fischbeck, K. H. Annu. Rev. Neurosci. 1996, 19, 79-107. 